\title{
Methylation of Spore DNA in Bacillus coagulans Strain 26
}

\author{
By AVELINO BUENO,* JULIO R. VillanueVA and TOMÁS G. Villa \\ Instituto de Microbiología Bioquímica, Facultad de Biología, Universidad de Salamanca/Consejo \\ Superior de Investigaciones Cientificas, 37071 Salamanca, Spain
}

(Received 16 January 1986; revised 11 June 1986)

The modification status of DNA throughout the life cycle of Bacillus coagulans strain 26 was analysed by restriction analysis with methylation-sensitive enzymes. A significant fraction of the GATC sequences (dam target) in spore DNA contain $N^{6}$-methyladenine, a modification that is lacking during the vegetative phase. From the modulation of the modification pattern of GATC sites, the existence of a de novo methylase may be inferred. Spore DNA was more sensitive than vegetative cell DNA to BamHI, $\mathrm{HpaI}$, SalI and $\mathrm{XhoI}$, indicating that the sites for these enzymes are modified during the vegetative growth phase.

\section{INTRODUCTION}

Prokaryotic DNA contains 5-methylcytosine $(5 \mathrm{mC}), N^{6}$-methyladenine $\left(N^{6} \mathrm{~mA}\right)$ (Vanyushin et al., 1968) and $N^{4}$-methylcytosine (Ehrlich et al., 1985) as modified bases, which are included (at least the former two) in specific sequences of four or more nucleotides which vary from species to species. In different strains of Bacillus subtilis, for example, up to six different sequences have been described which include $5 \mathrm{mC}$ (Jentsch, 1983). Although a relationship has been demonstrated between the methylation of specific sequences and the restrictionmodification ( $R / M)$ phenomenon (Günthert \& Trautner, 1984) and other functions have also been attributed to methylation (Hattman, 1981; Razin \& Friedman, 1981), such as the discrimination of parent and daughter strands for proofreading during DNA synthesis in Escherichia coli (Pukkila et al., 1983), the true biological significance of most DNA methylation and the diversity of modified specific sequences remain to be elucidated.

The role played by DNA methylation in B. subtilis, in which both $5 \mathrm{mC}$ and $N^{6} \mathrm{~mA}$ have been reported (Ganesan, 1979), is uncertain. Modulation of the modification pattern seems to be related to the physiological state of the cells (Günthert \& Trautner, 1984; Hattman, 1981), and hence populations which are competent for genetic transformation exhibit high levels of methylation activity (Ganesan, 1979). However, neither the genetic determinants, nor the specificity of the sequences affected by such activity, have been determined (Günthert \& Trautner, 1984). An increase has also been observed in methylation of cytosine in $B$. subtilis, Bacillus megaterium and Bacillus brevis during sporulation (Günthert, 1975; Guha, 1985), considered by many researchers as a primitive form of cellular differentiation, though up till now only speculations have been made regarding the true role of methylation in the regulation of sporulation.

In this work, prompted by our interest in sporulation in $B$. coagulans strain 26 , we present data concerning the analysis of the methylation of specific sequences during the life cycle of this micro-organism.

\section{METHODS}

Micro-organisms and culture conditions. B. coagulans strain 26 was isolated in our laboratory (Esteban et al., 1983). B. subtilis CECT 39 was from the Colección Española de Cultivos Tipo; B. subtilis NRRL B1490 and Bacillus macerans NCLB 7588 were gifts from Dr F. G. Priest, Heriot-Watt University, Edinburgh, UK. In each

Abbreviations: $N^{6} \mathrm{~mA}$ and $\mathrm{mA}, N^{6}$-methyladenine; $5 \mathrm{mC}$ and $\mathrm{mC}, 5$-methylcytosine; $\mathrm{R} / \mathrm{M}$, restrictionmodification. 
case the growth medium was YED (Esteban et al., 1983). Spores were isolated after $8 \mathrm{~h}$ incubation at $37^{\circ} \mathrm{C}$ in the resuspension medium described by Sterlini \& Mandelstam (1969); DNA purified from older spores was degraded and inadequate for restriction analysis.

Purification of DNA. DNA was purified from cells at different stages of growth following the method of Marmur (1961) with minor modifications which included isopycnic centrifugation in a CsCl gradient. DNA from spores was purified from a homogeneous preparation $(100 \%)$ according to the technique of Sargent $(1980 \mathrm{~b})$. The quality of each preparation was determined by the ratios $A_{260} / A_{280}(1 \cdot 8-1 \cdot 9)$ and $A_{260} / A_{230}(2 \cdot 0-2 \cdot 3)$ (Marmur, 1961).

Restriction conditions and densitometry. All digestions with restriction enzymes were done under the conditions recommended by suppliers. $\lambda$ DNA or pBR322 were used as internal controls to check that digestion was complete. Digested DNA was electrophoresed in horizontal agarose gels $(0 \cdot 7-1 \cdot 25, \mathrm{w} / \mathrm{v})$. The expected average size of fragments produced by digestion with a particular enzyme was calculated assuming that all nucleotides are randomly distributed as a function of the mean $\mathrm{mol} \% \mathrm{G}+\mathrm{C}$ of the micro-organism $(39.9 \%$ for $B$. coagulans strain 26: Esteban et al., 1983), assuming also a random distribution of the sites along the genophore. The observed size, i.e. the mean absorbance value (mode) was determined from the densitograms. All experiments were done at least twice to ensure reproducibility of results. Given the lack of appropriate isoschizomers to test the methylation status of the sites under study, we used enzymes with identical CG content in their recognition sites to compare the average size of the restriction fragments. We assumed that all dinucleotides have the same frequency. In double digestions these additional controls were conducted with two different enzymes. In no case were any significant differences observed between the expected size and the observed size for these controls. Fragment sizes were estimated by plotting the reciprocal of the migrated distance against the $M_{\mathrm{r}}$ of standard markers ( $\lambda$ HindIII or similar).

Average molecular sizes of distributions were estimated from the densitograms (absorbance/size) of photographs of the gels (negatives) obtained by transmission densitometry using a Schimadzu Dual-Wavelength TLC Scanner CS-910.

\section{RESULTS}

Distribution of sites for BamHI, HpaI, SalI and XhoI in DNA of B. coagulans strain 26

The predominance of high- $M_{\mathrm{r}}$ restriction fragments that were observed when DNA of $B$. coagulans strain 26 was analysed with BamHI, $H p a \mathrm{I}, \mathrm{SalI}$ and $X h o \mathrm{I}$ seemed to indicate that this DNA had few sites for these enzymes (Fig. 1). Spore DNA was more sensitive to digestion with the same enzymes, indicating that these sites were modified during the vegetative growth phase (see the legend of Fig. 1) and were demethylated during the sporulation process. As shown in Table 1, the demethylated $S a l I$ and $X h o I$ regions have a similar average size $(2.32 \mathrm{kbp})$, comparable to that of the BamHI region $(2 \cdot 1 \mathrm{kbp})$, and in all three cases it was significantly greater than that of the $H p a \mathrm{I}$ region $(1.65 \mathrm{kbp})$.

In all cases, the appearance of a demethylated region in spore DNA was accompanied by a decrease in the region of greatest $M_{\mathrm{r}}$ of the digests (Fig. $1 \mathrm{~A}$ and lanes $\mathrm{S}$ and 12 of Fig. 1 B); the sizes of these high $-M_{\mathrm{r}}$ fragments ranged between 15 and $48 \mathrm{kbp}$. Analysis of the densitograms obtained showed a log-normal distribution, from which it was possible to infer a clustering of the sites in the genome. When the DNAs were co-digested with SalI and XhoI (Fig. 1C), the observed size of the demethylated fraction $(1.71 \mathrm{kbp})$ did not vary as much from the predicted value $(1 \cdot 16 \mathrm{kbp})$ as might have been expected from the results of the single digestions, pointing to a clustering of $S a l I$ and $X h o I$ sites in the demethylated fraction. Analysis of the size distributions of DNA doubly digested with BamHI $+H p a I, B a m H I+S a l I, B a m H I+X h o I$, $H p a I+S a l I$ and $H p a I+X h o I$ showed a similar behaviour, pointing to the clustering of these sites in the demethylated fraction of the spore DNA also (data not shown).

\section{Distribution of the GMATC modification in spore DNA}

The modification of the GATC sites in the genophore of $B$. coagulans strain 26 was studied by using the isoschizomers Sau3A (cleaves GATC, and is insensitive to adenine methylation), $M b o I$ (cleaves at GATC when the sequence is not methylated) and DpnI (cleaves only when GATC is methylated on both strands). DNA purified during different stages of the life cycle of the micro-organism was resistant to DpnI, except the DNA from spores, which showed partial sensitivity (Fig. 2). The observed size of this DpnI-sensitive fraction (methylated on both strands) was $1.3 \mathrm{kbp}$. Control DNA from vegetative cells, not digested with $D p n I$, presented the 


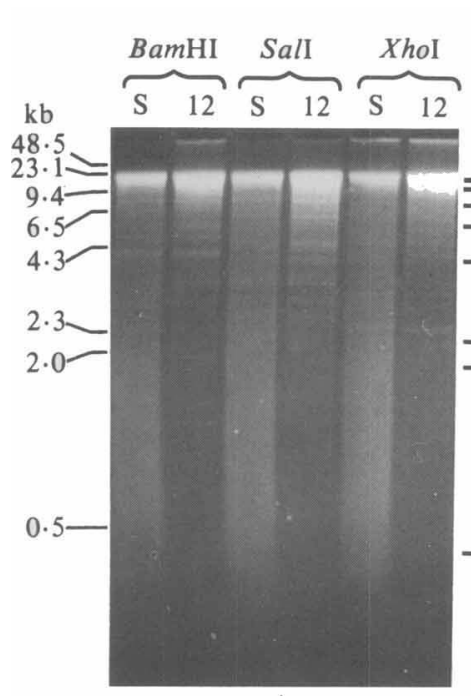

A

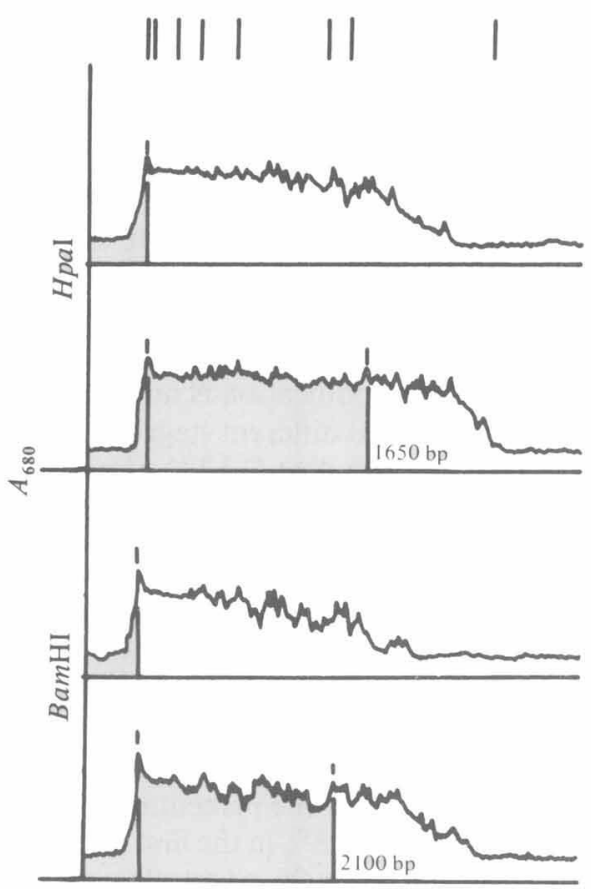

SalI

$\overbrace{\mathrm{S} \quad 12}^{+ \text {XhoI }} \overbrace{\mathrm{S} \quad 12}^{\text {BclI }} \overbrace{\mathrm{S} \quad 12}^{\text {PstI }}$

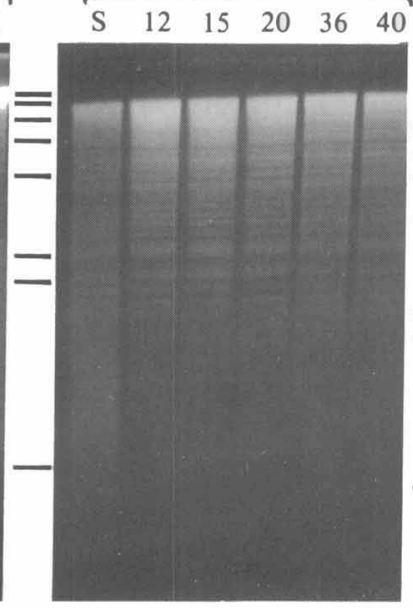

B

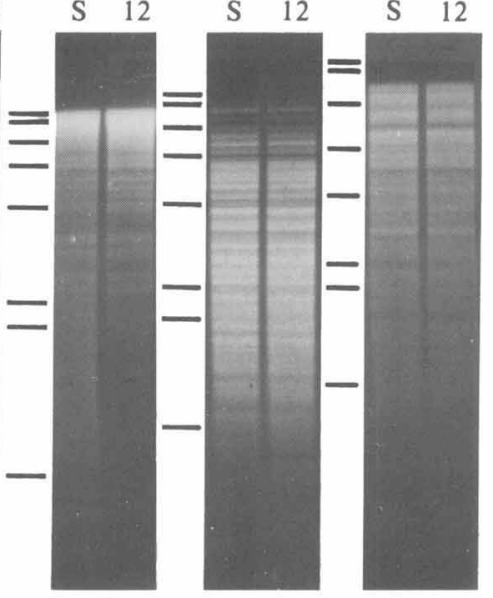

C

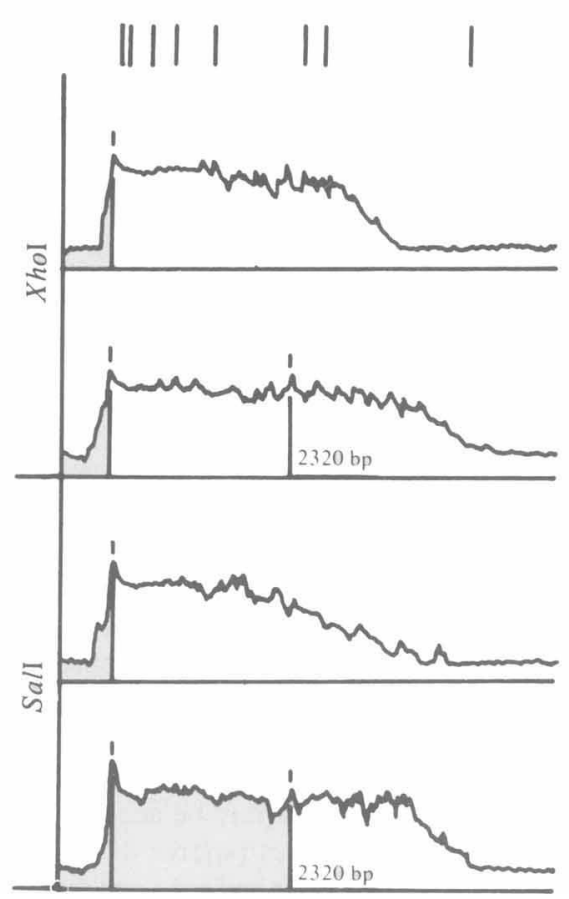

Fig. 1. Reduction in methylation of BamHI, HpaI, Sall and $X h o I$ sites ( $5 \mathrm{mC}$ and $N^{6} \mathrm{~mA}$ ) in spore DNA of $B$. coagulans strain 26. DNA from spores (S), and from vegetative cells in $12,15,20,36$ and $40 \mathrm{~h}$ cultures, was digested with BamHI, SalI, XhoI (A) and $H p a I$ (B), and co-digested with $S a l$ and $X h o I$ (C). BcII and PstI were used as controls (see Table 1). All the patterns of spore DNA show an increased sensitivity to endonuclease cleavage, indicating demethylation in these sites during spore differentiation. Densitometeric tracings are shown below. The semibimodal distributions obtained from spore DNA were interpreted by overlapping them with corresponding distributions from vegetative cell DNA. 
Table 1. Overrepresentation of the demethylated sites on spore DNA in B. coagulans strain 26

\begin{tabular}{|c|c|c|c|c|}
\hline $\begin{array}{l}\text { Restriction } \\
\text { enzyme* }\end{array}$ & $\begin{array}{c}\text { Assayed } \\
\text { DNA }\end{array}$ & $\begin{array}{c}\text { Expected } \\
\text { size (bp) } \\
(A)\end{array}$ & $\begin{array}{l}\text { Observed } \\
\text { size (bp) } \\
\text { (B) }\end{array}$ & $\begin{array}{l}\text { Percentage } \\
\text { over- } \\
\text { representation } \\
(C) \dagger\end{array}$ \\
\hline $\begin{array}{l}\text { BamHI } \\
\text { GGATmCC }\end{array}$ & $\begin{array}{l}\text { Spore } \\
12 \mathrm{~h}\end{array}$ & 6991 & $\left\{\begin{array}{r}23130 \\
2100 \\
23130\end{array}\right.$ & 232 \\
\hline $\begin{array}{l}\text { HpaI } \\
\text { GTTmAAC }\end{array}$ & $\begin{array}{c}\text { Spore } \\
12 \mathrm{~h}\end{array}$ & 3081 & $\left\{\begin{array}{r}23130 \\
1650 \\
23130\end{array}\right.$ & 86 \\
\hline $\begin{array}{l}\text { SalI } \\
\text { GTmCGAC }\end{array}$ & $\begin{array}{l}\text { Spore } \\
12 \mathrm{~h}\end{array}$ & 6991 & $\left\{\begin{array}{r}23130 \\
2320 \\
23130\end{array}\right.$ & 201 \\
\hline $\begin{array}{l}\text { XhoI } \\
\text { CTmCGAG }\end{array}$ & $\begin{array}{l}\text { Spore } \\
12 \mathrm{~h}\end{array}$ & 6991 & $\left\{\begin{array}{r}23130 \\
2320 \\
23130\end{array}\right.$ & 201 \\
\hline $\begin{array}{l}B c / I \\
\text { TGmATCA }\end{array}$ & $\begin{array}{l}\text { Spore } \\
12 \mathrm{~h}\end{array}$ & 3081 & 3200 & 0 \\
\hline $\begin{array}{l}\text { PstI } \\
\text { mCTGCAG }\end{array}$ & $\begin{array}{c}\text { Spore } \\
12 \mathrm{~h}\end{array}$ & 6991 & 7300 & 0 \\
\hline $\begin{array}{l}\text { SalI }+ \text { XhoI } \\
\text { GTmCGAC } \\
\text { CTmCGAG }\end{array}$ & $\begin{array}{c}\text { Spore } \\
12 \mathrm{~h}\end{array}$ & 3495 & $\left\{\begin{array}{rr}23 & 130 \\
1 & 706 \\
23 & 130\end{array}\right.$ & 104 \\
\hline
\end{tabular}

\footnotetext{
* Methylation of the recognition sequence as shown renders DNA insensitive to the enzyme. BclI and PstI were used as contrastive controls of unmodified sites for $2 \mathrm{G}$ or $\mathrm{C}$ and $4 \mathrm{~A}$ or $\mathrm{T}(B c / \mathrm{I})$ and $4 \mathrm{G}$ or $\mathrm{C}$ and $2 \mathrm{~T}$ or $\mathrm{A}(P s t \mathrm{I})$. + Calculated using the following equation: $C=[(A-B) / B] \times 100$.
}

same appearance as the DNA shown in Fig. 2, lanes 3-7, indicating that there is no DNA methylated in both strands at the GATC sites during the vegetative growth phase.

The absence of modification of $B c l$ I (TGmATCA) sites, as determined from the distribution of the restriction fragments (Table 1), and the identity of the restriction fragments between spores and vegetative cells (Fig. 1) indicate that the GmATC modification is not flanked, at $5^{\prime}$ and 3', respectively, by T and A. From analysis of DNA purified at different stages of vegetative growth using Sau3A and $M b o I$ it is possible to infer a lack of $N^{6} \mathrm{~mA}$ at GATC sites during the exponential growth phase and the beginning of the stationary phase. However, DNA purified during the later stationary phase exhibited a partial resistance to cleavage by $M b o I$; the DNA from $36 \mathrm{~h}$ cultures was more refractory to digestion than that from $40 \mathrm{~h}$ cultures (data not shown). From the joint interpretation of the analysis of these DNA samples with DpnI, Sau3A and $M b o I$, it may be seen that as the sporulation process begins, de novo methylase activity is induced with GmATC specificity which first modifies one strand, with the appearance of hemimethylated DNA (36 and $40 \mathrm{~h}$ ), then the antiparallel strand, either before or at the same time as DNA is packaged in the spore. The greater modification observed in the $36 \mathrm{~h}$ DNA compared with that of $40 \mathrm{~h}$ may be accounted for in this context by the percentage of spores at these times; the value [spores/(spores + vegetative cells)] $\times 100$ is $28 \%$ in the first case and $41 \%$ in the second (it should be taken into account that B. coagulans strain 26 is very efficient in spore formation).

Electrophoresis of the $\mathrm{MboI}$ restriction fragments of spore DNA revealed two fractions in distributions of GmATC sites (Fig. 3). One fraction has all its GATC sites modified; this region shows slightly greater mobility than undigested DNA with an approximate size of $40 \mathrm{kbp}$. Furthermore, analysis with $D p n I$ shows that it is a region statistically poor in GATC sites. The second fraction is partially resistant to $\mathrm{MboI}$ and exhibits modified sites intercalated between unmodified ones. The densitograms obtained from the restriction analysis (Fig. 3) show that about $75 \%$ of the GATC sites in the second fraction are modified, since the observed average sizes of $M b o I$ and Sau3A fragments were $0.52 \mathrm{kbp}$ and $0.13 \mathrm{kbp}$, respectively. 


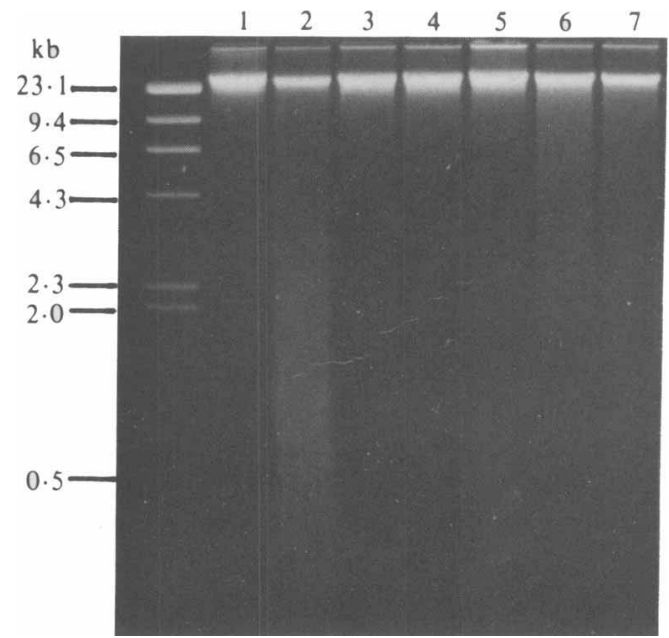

Fig. 2. Extent of methylation of GATC $\left(N^{6} \mathrm{~mA}\right)$ sites in spore DNA of $B$. coagulans strain 26. DNA from spores, and from vegetative cells in $12,15,20,36$ and $40 \mathrm{~h}$ cultures, was digested with $D p n I$ (cleaves only when GATC is methylated in both strands). (1) Undigested spore DNA. (2-7) DpnItreated DNA from: spores (2); mid-exponential phase cells, $12 \mathrm{~h} \mathrm{(3);} \mathrm{late} \mathrm{exponential} \mathrm{phase} \mathrm{cells,} 15 \mathrm{~h}$ (4); early stationary phase cells, $20 \mathrm{~h}(5)$; late stationary phase cells, $36 \mathrm{~h}(6)$; late stationary phase cells, $40 \mathrm{~h}(7)$.
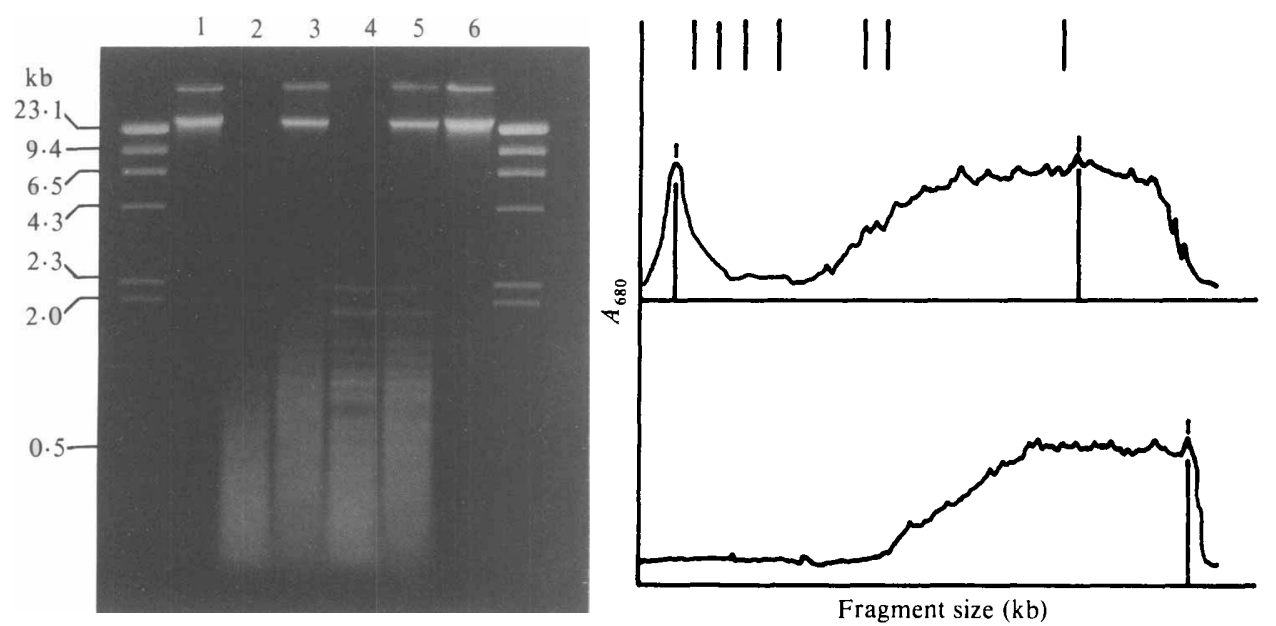

Fig. 3. Distribution of the GmATC sequence in spore DNA of $B$. coagulans strain 26. Spore DNA (l $\mu \mathrm{g})$ was digested with Sau3A and $M b o I$ ( 2 units per $\mu$ g DNA); the digested DNAs were electrophoresed on $1 \%$ agarose gels, stained with ethidium bromide and photographed, and the negatives were scanned as described in Methods. (1) and (6) undigested spore DNA; (2) and (4) Sau3A-treated spore DNA; (3) and (5) $M$ bol-treated spore DNA. $\lambda$ DNA was added to the DNA samples in lanes, (4) and (5) to test for complete digestion. Densitometric tracings of the negatives obtained of Sau $3 \mathrm{~A}$ and $\mathrm{MboI}$ digests are also shown.

\section{DISCUSSION}

Following the idea that the biological significance of DNA methylation must be reflected in the distribution pattern of the modified bases in DNA (Szyf et al., 1982), we studied the modulation of the modification pattern of the genophore of $B$. coagulans strain 26 for the sequences GGATCC, GTTAAC, GTCGAC, CTCGAG and GATC. In all cases a nonrandom distribution of sites was observed and in the last one there was a non-random 
distribution of the modified sites. These non-random distributions suggest that base modification may play a specific role related to the sporulation process. The role of these modifications in sporulation itself, i.e. whether they are the cause or a consequence of sporulation processes, remains to be determined.

The partial methylation observed at BamHI, HpaI, SalI and XhoI sites may be accounted for in terms of partial methylation in vivo; there is growing evidence to suggest that not all potentially methylatable sites are modified as reported by Razin \& Friedman (1981). Guha (1985) reported that only some TTmCGAA sites are methylated in vivo in B. subtilis Marburg 168. Similar observations have been described by Vanyushin \& Dobrista (1975) for B. brevis. The possible alternative, i.e. that one might be dealing with populations with a significant proportion of mutants deficient in $\mathbf{R} / \mathbf{M}$ systems, similar to the $\mathrm{HsdM}^{-}$and $\mathrm{HsdR}^{-}$mutants described in Haemophilus influenzae (Glover \& Piekarowicz, 1972), is rejected by us since DNA analysis of homogeneous spore populations shows similar patterns, pointing to a non-random distribution of these four sites in the genophore of the bacillus; this distribution phenomenon in prokaryotic DNA such as that of E. coli is not unfamiliar (Razin \& Friedman, 1981).

Both the partial modification of these sites and their asymmetric distribution in the genophore indicate that they are probably not involved in the classic function described for $\mathbf{R} / \mathbf{M}$ systems. In this sense, it should be noted that for cellular defence, $R / M$ systems with four-base-pair recognition sequences are much more useful than those with six. In this context it is highly significant that the methylases coded by $B$. subtilis phages are able to recognize and modify sequences such as GGCC, CCGG and GCNGC (Günthert \& Trautner, 1984). Such ideas seem to be unrelated to results which point to some role other than that assigned to $R / M$ systems for DNA methylation, though it is very interesting to note that the only $R / M$ system whose regulation has been studied in depth shows that there is a close connection between sporulation efficiency and the expression of BsuM restrictase (Fucik et al., 1982) whose specificity, 5'PyTmCGAR3', has recently been determined (Guha, 1985).

There is contradiction between the methylation observed by us (BamHI, $\mathrm{HpaI}, \mathrm{SalI}$ and $\mathrm{XhoI})$ and the results of Günthert (1975) during spore formation in $B$. subtilis, B. megaterium and $B$. brevis, in which a marked increase in $5 \mathrm{mC}$ was reported. Guha (1985) has stated that during sporulation of $B$. subtilis Marburg 168 a small increase may be observed in amounts of $5 \mathrm{mC}$. Although we still do not know whether the total $5 \mathrm{mC}$ and $N^{6} \mathrm{~mA}$ content decreases in the genophore packaged in the spores of $B$. coagulans strain 26 , the demethylation observed at these four sites favours the hypothesis that DNA methylation might play a role in sporulation (Freese et al., 1984).

The most surprising aspect of all this is the GmATC modification observed in the DNA of spores of this micro-organism. Although Dreiseikelmann \& Wackernagel (1981) noted an absence of dam modification in B. subtilis Marburg 168, our results might not be in disagreement with theirs, since they analysed modification during the competent state and not during sporulation. However, analysis of spore DNA from B. subtilis strains NRRL B1490 and CECT 39 shows the absence of dam modification in them. This modification does exist in spores of $B$. macerans NCLB 7588 , but it is also observed during the vegetative phase (unpublished observations).

From our point of view there is no relationship between increased activity of prophages (in particular their methylases) during development of competence (Yasbin, 1977; Ganesan, 1979; Trautner et al., 1980) and sporulation. There are some significant differences between the methylase system induced in competent cells, which is perhaps correlated with the activation or derepression of the SOS system (Yasbin, 1977), and that which is associated with the sporulation process, as described here. Even though nutrient starvation induces competence, sporulation and the SOS response, sporulation is regarded as a differentiation process (Sonenshein, 1984), not a physiological state. It involves cell differentiation, rather than a cessation of growth.

An important deduction arising from the modulation of the modification pattern of the GATC sequence during sporulation is the existence of a de novo methylase. Since the need has been demonstrated for a complete replication of the genophore during spore formation (Sargent, $1980 a$; Binnie \& Coote, 1983), DNA methylation probably accompanies such replication during 
the process which eventually leads to its packaging. The fact that DNA methylated in both strands is not found in vegetative cells, even when analysed in a population with a high proportion of sporulating cells, suggests that methylation at GATC might allow discrimination between the genophore to be packaged and the DNA to be degraded between the daughter cells; this idea, however, is highly speculative.

We wish to thank Drs C. Nombela, A. Durán and F. del Rey for a critical reading of the manuscript and F. Antequera for valuable discussions. We thank N. Skinner for translating the Spanish version of the manuscript.

\section{REFERENCES}

BINNIE, C. \& CoOTE, J. G. (1983). Density gradient analysis of DNA replicated during Bacillus subtilis sporulation. Journal of Bacteriology 156, 466-470.

DREISEIKELMANN, B. \& WACKERNAGEL, W. (1981). Absence in Bacillus subtilis and Staphylococcus aureus of the sequence-specific deoxyribonucleic acid methylation that is conferred in Escherichia coli $\mathrm{K}-12$ by the dam and dcm enzymes. Journal of Bacteriology 147, 259-261.

Ehrlich, M., Gama-Sosa, M. A., Carreira, L. A., LJungdahl, L. G., Kwo, K. C. \& Gehrke, Ch.W. (1985). DNA methylation in thermophilic bacteria. $N^{4}$-methylcytosine, 5-methylcytosine, and $N^{6}$. methyladenine. Nucleic Acids Research 13, 13991412.

Esteban, R., Chordi, A. \& Villa, T. G. (1983). Some aspects of a 1,4- $\beta$-D-xylanase and a $\beta$-D-xylosidase secreted by Bacillus coagulans str. 26. FEMS Microbiology Letters 17, 163-166.

Freese, E., Freese, E. B., Allen, A. R., OlempskaBeer, Z., OrRego, C., Varma, A. \& Wabiko, H. (1984). Metabolic initiation of spore development. In Molecular Biology of Microbial Differentiation, pp. 194-202. Edited by J. A. Hoch \& P. Setlow. Washington, DC: American Society for Microbiology.

Fucik, V., GrunNerova, H. \& ZadrazIL, S. (1982). Restriction and modification in Bacillus subtilis Marburg 168. Regulation of $h s r M$ (non $B$ ) expression in spoOA mutants and effects on permissiveness for $\varphi 15$ and $\varphi 105$ phages. Molecular and General Genetics 186, 118-121.

GANESAN, A. T. (1979). Genetic recombination during transformation in Bacillus subtilis: appearance of a deoxyribonucleic acid methylase. Journal of Bacteriology 139, 270-279.

Glover, S. W. \& Piekarowicz, A. (1972). Host specificity of DNA in Haemophilus influenzae: restriction and modification in strain Rd. Biochemical and Biophysical Research Communications 46, 1610-1617.

GUHA, S. (1985). Determination of DNA sequences containing methylcytosine in Bacillus subtilis Marburg. Journal of Bacteriology 163, 573-579.

GÜNTHERT, U. (1975). DNA Methylierung während der Entwicklung von Pro- und Eukaryoten. PhD thesis, University of Tübingen.

Günthert, U. \& Trautner, T. A. (1984). DNA methyltransferases of Bacillus subtilis and its bacteriophages. Current Topics in Microbiology and Immunology 108, 11-22.

Hattman, S. (1981). DNA methylation. The Enzymes 12A, 517-547.
JENTSCH, S. (1983). Restriction and modification in Bacillus subtilis: sequence specificities of restriction/ modification systems BsuM, BsuE, and BsuF. Journal of Bacteriology 156, 800-808.

MARMUR, J. (1961). A procedure for isolation of deoxyribonucleic acid from microorganisms. Journal of Molecular Biology 3, 208-218.

Pukkila, P. J., Peterson, J., Herman, G., Modrich, P. \& Meselson, M. (1983). Effects of high levels of DNA adenine methylation on methyl-directed mismatch repair in Escherichia coli. Genetics 104, 571582.

RAzIN, A. \& Friedman, J. (1981). DNA methylation and its possible biological roles. Progress in Nucleic Acid Research and Molecular Biology 25, 33-52.

SARGENT, M. G. $(1980 a)$. Chromosome replication in sporulating cells of Bacillus subtilis. Journal of Bacteriology 142, 491-498.

SARGENT, M. G. (1980 $b$ ). A procedure for isolating high quality DNA from spores of Bacillus subtilis 168. Journal of General Microbiology 116, 511-514.

SoNENSHEIN, A. L. (1984). Recent progress in metabolic regulation of sporulation. In Molecular Biology of Microbial Differentiation, pp. 185-193. Edited by J. A. Hoch \& P. Setlow. Washington, DC: American Society for Microbiology.

Sterlini, J. M. \& Mandelstam, J. (1969). Commitment to sporulation in Bacillus subtilis and its relationship to development of actinomycin resistance. Biochemical Journal 113, 29-37.

SzyF, M., Gruenbaum, Y., URIEli-Shoval, S. \& RAZIN, A. (1982). Studies on the biological role of DNA methylation. V. The pattern of $E$. coli DNA methylation. Nucleic Acids Research 10, 7247-7259.

Trautner, T. A., PaWlek, B., GüNthert, Ù., Canosi, U., Jentsch, S. \& Freund, M. (1980). Restriction and modification in Bacillus subtilis: identification of a gene in the temperate phage SP $\beta$ coding for a BsuR specific modification methyltransferase. Molecular and General Genetics 180, 361367.

Vanyushin, B. F. \& Dobrista, A. P. (1975). On the nature of the cytosine methylated sequence of Bacillus brevis var. G.B. Biochimica et biophysica acta 407, 61-72.

Vanyushin, B. F., Belozerksy, A. N., Kokurina, N. A. \& Kadirova, D. X. (1968). 5-Methylcytosine and 6-methylaminopurine in bacterial DNA. Nature, London 218, 1066-1067.

YASBIN, R. E. (1977). DNA repair in Bacillus subtilis. Molecular and General Genetics 153, 219-225. 